\title{
HAK ATAS TANAH DENGAN BUKTI GIRIK SEBAGAI OBYEK JAMINAN UTANG DAN PERLINDUNGAN HUKUM TERHADAP KREDITOR
}

\author{
Ari Wibowo, Siti Malikhatun Badriyah, Adya Paramita Prabandari \\ Program Studi Magister Kenotariatan \\ Fakultas Hukum, Universitas Diponegoro \\ E-mail: ariwibowolink@gmail.com
}

\begin{abstract}
Many lands owned by the community that do not yet have certificates, whereas the evidence they have is only in the form of Girik (Letter C), which is only proof of payment of tax, not proof of land rights. Therefore, its position in the modern economic era will be a polemic when the land is used as collateral for banks to obtain credit as venture capital. This study uses a sociological juridical approach, namely by observing the enactment of law in the community, among others, comparing the laws and regulations with the implementation of giving credit with Girik (Letter C) proof as collateral. This study aims to find out the implementation of Bank Indonesia Regulation Number 13/26/PBI/2011 in according to Act of Republic of Indonesia Number 4 Year 1996 concerning Mortgage and Objects Related to Land and Government Ordinance of Republic of Indonesia Number 24 Year 1997 concerning Land Registration and how to protect the law against creditors in the event of a default from the debtor that provides Girik. The results of the study show that Girik (Letter C) is not proof of ownership of land rights as stipulated in the legislation, but only as proof of payment of taxes. However, Girik is one of the proofs as a condition for the legal registration of rights to land. In addition to protecting creditors as holders of mortgage rights, a Notary / PPAT can be requested to make SKMHT together with land registration, can it be tied up with the APHT
\end{abstract}

Keywords: land property rights with girik evidence (letter c); mortgage; legal protection.

\begin{abstract}
Abstrak
Tanah-tanah yang dimiliki masyarakat masih banyak yang belum mempunyai sertipikat sedangkan bukti yang mereka miliki hanyalah berupa Girik (Letter $C$ ) yang hanya merupakan bukti pembayaran pajak bukan bukti alas hak atas tanah. Oleh karena itu kedudukannya di era ekonomi modern ini akan menjadi polemik ketika tanah tersebut dijadikan jaminan bank untuk memperoleh kredit sebagai modal usaha. Penelitian ini menggunakan metode pendekatan Yuridis sosiologis, yaitu dengan melihat berlakunya hukum di masyarakat antara lain membandingkan peraturan perundang-undangan dengan pelaksanaan pemberian kredit dengan bukti Girik (Letter $C$ ) sebagai jaminan. Penelitian ini bertujuan untuk mengetahui apakah implementasi Peraturan Bank Indonesia Nomor :13/26/PBI/2011 sesuai dengan Undang-Undang Nomor 4 Tahun 1996 dan Peraturan Pemerintah Nomor 24 tahun 1997 dan bagaimana perlindungan hukum terhadap kreditor jika terjadi wanprestasi dari pihak debitor yang memberikan jaminan tanah berupa Girik. Hasil penelitian menunjukan bahwa Girik (Letter $C$ ) bukan merupakan bukti kepemilikan hak atas tanah, melainkan hanya sebagai bukti pembayaran pajak. Namun demikian, Girik merupakan salah satu bukti sebagai syarat pendaftaran hak atas tanah yang sah. Selain itu untuk melindungi kreditor sebagai pemegang hak tanggungan, dapat dimintakan bantuan Notaris/PPAT untuk dibuatkan SKMHT bersama-sama dengan pendaftaran tanah, baru kemudian dapat diikat dengan APHT.
\end{abstract}

Kata kunci : hak atas tanah dengan bukti girik (letter c); hak tanggungan; perlindungan hukum; 


\section{A. Pendahuluan}

Kurang atau minimnya bukti kepemilikan atas tanah, menjadi penyebab permasalahan dalam pemberian kredit oleh bank. Hal ini dikarenakan minimnya pengetahuan masyarakat akan arti pentingnya bukti kepemilikan hak atas tanah. Oleh karena itu perlu kajian-kajian yang mendalam atas tanah yang masih berstatus Girik dengan tujuan jaminan kredit yang preferen.

Tanah yang minim bukti kepemilikannya tersebut biasanya hanya berupa surat Letter C yang diperoleh dari kantor desa atau kelurahan dimana tanah tersebut berada. Surat Letter C ini merupakan tanda bukti berupa catatan-catatan yang berada di kantor desa. Masyarakat desa cenderung mengartikan bukti Letter $\mathrm{C}$ ini sebagai bukti sah kepemilikan atas tanah, padahal secara hukum bukti ini sangatlah lemah sehingga rawan disalahgunakan karena keterangan di dalam bukti Letter C yang ada pada kantor desa sangatlah tidak lengkap dan pencatatannnya cenderung tidak teliti.

Surat Letter C ini sebenarnya hanya dijadikan sebagai dasar catatan penarikan pajak bumi dan bangunan yang tentu saja kutipan dari surat tersebut hanya menginduk kepada Kantor Pelayanan Pajak bukan kepada Badan Pertanahan Nasional. Sedangkan masyarakat sebagai pemilik tanah hanya memiliki alat bukti Girik sebagai bukti pembayaran pajak atas tanah yang juga dikenal dengan nama Verponding Indonesia.

Selain itu di Indonesia menganut sistem Pendaftaran Tanah dengan Stelsel Negatif. Sejarah kepemilikan tanah secara individual jika hanya mengandalkan kepada ingatan atau keterangan saksi pasti tidak teliti, karena ingatan bisa saja kabur dan saksi-saksi hidup suatu saat akan meninggal dunia. Di Indonesia, tanah sudah ada sejak lama dalam artian bahwa hubungan manusia dengan tanah telah ada sejak dahulu, namun karena tidak tertulis apalagi tidak terdaftar hanya secara lisan diketahui tanah itu milik siapa dan batas-batasnya, atau setidak-tidaknya suatu bidang tanah itu menurut umum diketahui adalah milik seseorang ataupun warisan seseorang pada ahli warisnya.

Sementara itu praktik pengikatan kredit bagi masyarakat dengan jaminan tanah berupa Girik masih memungkinkan diberikan peluang oleh ketentuan hukum berdasarkan UndangUndang Nomor 4 Tahun 1996 Tentang Hak Tanggungan Atas Tanah Beserta Benda-Benda Yang Berkaitan Dengan Tanah (UUHT), disebutkan bahwa pembeban hak tanggungan dapat dilakukan untuk tanah yang sudah terdaftar, tetapi juga dapat dimungkinkan terhadap tanah yang belum terdaftar.

Perjanjian kredit dengan pengikatan jaminan tanah dengan bukti girik tanpa lembaga hak tanggungan dan tanpa adanya proses pendaftaran tanah lebih lanjut seharusnya tidak dapat 
dilakukan karena bertentangan dengan aturan yang berlaku. Namun pada Pasal 10 Ayat (3) UUHT sebagaimana dijelaskan diatas, mewajibkan Pengikatan jaminan tanah dengan bukti girik dalam pemberian hak tanggungannya harus bersamaan dengan permohonan pendaftaran hak atas tanahnya.

Bank Perkreditan Rakyat (BPR) memiliki peranan yang penting dalam mendukung perkembangan Usaha Mikro, Kecil dan Menengah (UMKM) melalui fungsi pokoknya yaitu menghimpun dana masyarakat dan menyalurkan kredit. Untuk mendukung peranan BPR tersebut, Bank Indonesia pada tahun 2006 telah mengeluarkan pengaturan tentang pedoman pemberian kredit pada BPR yaitu PBI Nomor 8/19/2006 Tentang Kualitas Aktiva Produktif dan Pembentukan Penyisihan Kualitas Aktiva Produktif Bank Perkreditan Rakyat, selanjutnya agar relevan dengan perkembangan Akuntansi BPR, harus disesuaikan dengan Standar Akuntansi Keuangan untuk Entitas Tanpa Akuntabilitas Publik (SAK ETAP) bagi BPR dan Pedoman Akuntansi Bank Perkreditan Rakyat (PA BPR), kemudian pengaturan ini diubah dengan PBI Nomor 13/26/2011 Tentang Kualitas Aktiva Produktif dan Pembentukan Penyisihan Kualitas Aktiva Produktif (PBI BPR).

Oleh karena tanah sangat penting kedudukannya bagi umat manusia, dan masih banyak masyarakat dalam menjalankan usahanya memerlukan modal berupa pinjaman dari bank dengan jaminan tanah, sedangkan masih banyak pula tanah-tanah di Indonesia yang bukti kepemilikannya masih berupa Girik (Letter C). Oleh karena itu perlu suatu kajian yang mendalam terhadap permasalahan ini baik melalui obyek penelitian berupa kebijakan peraturan perundang-undangan maupun yang terjadi di lapangan.

Berdasarkan latar belakang tersebut, penulis tertarik dan ingin menulis dengan judul "Hak Atas Tanah Dengan Bukti Girik Sebagai Obyek Jaminan Utang Dan Perlindungan Hukum Terhadap Kreditor (Tinjauan Yuridis terhadap Penerapan Peraturan Bank Indonesia Nomor :13/26/PBI/2011)" dengan rumusan masalah sebagai berikut :

1. Apakah implementasi Peraturan Bank Indonesia Nomor :13/26/PBI/2011 sesuai dengan Undang-Undang Nomor 4 Tahun 1996 Tentang Hak Tanggungan Atas Tanah Beserta Benda-Benda Yang Berkaitan Dengan Tanah dan Peraturan Pemerintah Nomor 24 tahun 1997 tentang Pendaftaran Tanah?

2. Bagaimana perlindungan hukum terhadap kreditor jika terjadi wanprestasi dari pihak debitor yang memberikan jaminan tanah berupa Girik?

\section{B. Metode Penelitian}


Dalam penulisan ini, penulis menggunakan metode penelitian kualitatif. Penelitian kualitatif menurut Bogan dan Tailor adalah prosedur penelitian yang menghasilkan data deskriptif berupa kata-kata tertulis maupun lisan dari orang-orang dan pelaku yang diamati (Moleong, 2009).

Penelitian hukum dapat dibedakan menjadi penelitian hukum normatif dan penelitian hukum sosiologis. Penelitian hukum normatif dilakukan dengan cara meneliti bahan pustaka yang merupakan data sekunder dan disebut juga penelitian hukum kepustakaan. Penelitian hukum sosiologis atau empiris terutama meneliti data primer.

\section{Metode Pendekatan}

Metode pendekatan yang dipergunakan dalam penelitian ini adalah metode pendekatan yuridis sosiologis. Pendekatan yang bersifat yuridis sosiologis yaitu suatu pendekatan yang melihat berlakunya hukum di dalam masyarakat. Hal ini biasanya mendapat pengaruh dari masyarakat yang mendukungnya. Penelitian di lapangan melalui pendekatan yuridis sosiologis dengan cara wawancara dengan petugas bank untuk mendeskripsikan fenomena yang terjadi dalam hukum jaminan terkait dengan girik sebagai jaminan bank. Kemudian penulis menganalisis menggunakan berbagai literatur dan peraturan perundang-undangan yang berlaku.

\section{Spesifikasi Penelitian}

Spesifikasi penelitian yang digunakan dalam penelitian ini adalah deskriptif analitis. Karena penelitian ini menggambarkan perundang-undangan yang berlaku yang berkaitan dengan teori-teori ilmu hukum dan suatu keadaan atau Obyek tertentu secara faktual dan akurat yang kemudian menganalisis data yang diperoleh dari penelitian. Pada dasarnya metode deskriptif analitis merupakan suatu gambaran mengenai kejadian-kejadian di lapangan kemudian menganalisis data yang ada.

\section{Sumber dan Jenis Data}

Sumber data yang digunakan dalam penelitian ini adalah bersumber dari data primer yang terdiri dari data laporan keuangan serta hasil wawancara dengan Pimpinan BPR Artha Mekar Sokaraja Cabang Cilacap, dan dari data sekunder diperoleh malalui berbagai peraturan perundang-undangan, literatur maupun daftar pustaka lainnya.

\section{Teknik Pengumpulan Data}

Adapun teknik pengumpulan data dilakukan dengan cara :

a. Studi Kepustakaan yaitu data sekunder yang diperoleh dengan mempelajari literatur, kumpulan bahan kuliah, konsep-konsep, doktrin-doktrin dan peraturan perundang- 
undangan yang berhubungan dengan permasalahan yang diteliti.

b. Studi lapangan yaitu sebagai data pendukung dilakukan untuk mendapatkan data primer yaitu dengan mengadakan wawancara kepada Pimpinan Cabang Bank Perkreditan Rakyat Artha Mekar Sokaraja (BPR AMS) Cabang Cilacap.

\section{Teknik Analisis Data}

Pengolahan dan analisis data dalam penelitian ini dilakukan dengan metode analisis normatif kualitatif yaitu proses analisa terhadap data yang terdiri dari kata-kata yang dapat ditafsirkan, yaitu data yang diperoleh di lapangan dalam bentuk tulisan dan segera dianalisa (Nasution, 1986). Maksudnya semua data yang terkumpul baik dari hasil penelitian kepustakaan (data sekunder) dan penelitian lapangan (data primer) disusun secara sistematis yang kemudian dianalisis dengan menggunakan teori-teori dan peraturan perundangundangan yang berlaku agar dapat ditarik kesimpulan guna mendapatkan kejelasan mengenai permasalahan yang diteliti.

\section{Hasil Penelitian Dan Pembahasan}

1. Implementasi Peraturan Bank Indonesia Nomor :13/26/PBI/2011 berkaitan dengan Undang-Undang Nommor 4 Tahun 1996 tentang Hak Tanggungan Atas Tanah Beserta Benda-Benda Yang Berkaitan Dengan Tanah dan Peraturan Pemerintah Nomor 24 tahun 1997 tentang Pendaftaran Tanah

UUPA telah mengatur tentang hak jaminan yang dinamakan hak tanggungan namun pengaturannya sangat terbatas sehingga belum dapat dilaksanakan secara nasional. Kemudian dengan dikeluarkannya Undang-Undang No. 4 Tahun 1996 tentang Hak Tanggungan atas Tanah dan Benda-benda yang Berkaitan dengan Tanah (UUHT), terbentuklah suatu struktur hukum jaminan nasional, sebagaimana yang diamanatkan dalam Pasal 51 UUPA. Pasal 1 UUHT menyebutkan bahwa pengertian dari Hak Tanggungan adalah jaminan yang dibebankan atas tanah sebagaimana dimaksud dalam UUPA, yang mana obyek yang dapat dibebani dengan Hak Tanggungan adalah hak-hak atas tanah dan benda-benda yang berkaitan dengan tanah.

Obyek hak tanggungan ini termuat dalam Pasal 4 UUHT sebagaimana juga disebutkan dalam UUPA yaitu Hak Milik (Pasal 25), Hak Guna Usaha (Pasal 33) dan Hak Guna Bangunan (Pasal 39). Selain itu hak pakai atas tanah negara juga harus didaftarkan dan karena menurut sifatnya dapat dipindahtangankan maka dapat pula dijadikan obyek hak tanggungan. Oleh karena itu hak-hak yang dapat dijadikan hak tanggungan harus memenuhi 
2 (dua) persyaratan yaitu wajib didaftarkan untuk memenuhi asas publisitas dan dapat dipindahtangankan untuk menjamin pembayaran atau pelunasan utang apabila terjadi wanprestasi oleh debitor. Kedua syarat tersebut harus terpenuhi dalam setiap obyek yang dibebankan hak tanggungan.

Berdasarkan Undang-undang Perbankan, BPR merupakan salah satu jenis bank yang kegiatan utamanya adalah menghimpun dana masyarakat dan menyalurkan kredit. Proses penyaluran kredit tersebut diatur dalam Peraturan Bank Indonesia (PBI) Nomor 13/26/PBI/2011 tentang Perubahan Atas Peraturan Bank Indonesia Nomor 8/19/PBI/2006 Tentang Kualitas Aktiva Produktif Dan Pembentukan Penyisihan Penghapusan Aktiva Produktif Bank Perkreditan Rakyat.

Terhadap kredit dengan agunan tanah dan/atau bangunan dengan bukti kepemilikan berupa Girik (Letter C) mempunyai perlakuan khusus. Proses pemberian kredit tetap harus disertai dengan agunan sebagai jaminan antara lain jaminan berupa tanah dan /atau bangunan. Meskipun bukti kepemilikan tanah dan/atau bangunan tersebut masih dalam bentuk Girik (Letter C) sebagaimana telah diketahui bahwa Girik (Letter C) tersebut bukanlah merupakan bentuk bukti hak kepemilikan atas suatu tanah, namun hal tersebut tidak menutup kemungkinan dapat dijadikan sebagai jaminan pemberian kredit oleh BPR AMS.

Dalam proses pemberian kredit sebenarnya sama dengan pemberian kredit dengan jaminan sertipikat tanah pada umumnya, hanya saja setelah proses penilaian dan survey terhadap obyek tanah selesai, proses selanjutnya adalah melalui bantuan notaris/PPAT, tanah tersebut didaftarkan terlebih dahulu ke BPN untuk diterbitkan sertipikat tanah. Nah, untuk mempercepat proses pencairan kredit, tentu BPR membutuhkan instrumen sebagai dasar pencairan kredit yaitu berupa cover note dari notaris/PPAT yang menyatakan bahwa tanah tersebut sedang dalam proses penyertifikatan tanah dan untuk memastikan bahwa tanah tersebut benar-benar sedang didaftarkan. Itulah sebabnya harus melalui bantuan PPAT meskipun sebenarnya pendaftaran tanah dapat dilakukan secara mandiri.

Hal ini sejalan dengan amanat Undang-Undang Hak Tanggungan (UUHT) Nomor 4 Tahun 1996 Tentang Hak Tanggungan Dan Benda-Benda Yang Berkaitan Dengan Tanah Pasal 10 Ayat (3) dimana disebutkan bahwa "Apabila obyek Hak Tanggungan berupa hak atas tanah yang berasal dari konversi hak lama yang telah memenuhi syarat untuk didaftarkan akan tetapi pendaftarannya belum dilakukan, pemberian Hak Tanggungan dilakukan bersamaan dengan permohonan pendaftaran hak atas tanah yang bersangkutan“.

Pengaturan mengenai diberikan kesempatan bagi pemilik hak atas tanah yang belum 
bersertifikat untuk bisa menggunakan tanahnya sebagai jaminan dalam suatu perjanjian antara lain dalam perjanjian kredit untuk memperoleh dana, disamping untuk melindungi golongan ekonomi lemah, juga untuk mendorong dilakukannya pensertifikatan hak atas tanah yang dijadikan objek Hak Tanggungan (Badriyah, 2016).

Dengan demikian, mengingat setiap obyek hak tanggungan harus memenuhi syarat harus didaftarkan, maka untuk tanah-tanah yang belum memiliki sertipikat, seperti tanahtanah yang hanya memiliki bukti Girik (Letter C), maka bukan termasuk salah satu obyek hak tanggungan sebagaimana yang ditetapkan oleh UUPA. Agar tanah-tanah dengan bukti Girik tersebut mendapatkan legalitas kepemilikannya maka dapat dimintakan permohonan pendaftaran haknya untuk pertama kali berdasarkan ketentuan Peraturan Pemerintah Nomor 24 Tahun 1997 tentang Pendaftaran Tanah (PP Pendaftaran Tanah), yaitu terdapat 2 (dua) jenis pendaftaran tanah untuk pertama kali (belum pernah didaftar berdasarkan PP Pendaftaran Tanah) yaitu secara sistematik dan periodik.

Dengan demikian jelaslah bahwa Girik (Letter C) bukan merupakan bukti kepemilikan hak atas tanah berdasarkan UUPA melainkan hanya sebagai bukti pembayaran Pajak saja. Namun dalam kedudukannya, Girik (Letter C) sebagaimana dalam ketentuan peraturan perundang-undangan dapat dijadikan sebagai dasar atau alat bukti tertulis untuk pendaftaran tanah.

Dengan demikian, ketentuan yang ada dalam PBI Nomor 13/26/PBI/2011 masih diterapkan oleh BPR AMS dengan mengacu kepada Undang-Undang Nomor 4 Tahun 1996 Tentang Hak Tanggungan Dan Benda-Benda Yang Berkaitan Dengan Tanah dan Peraturan Pemerintah Nomor 24 Tahun 1997 Tentang Pendaftaran Tanah sebagaimana amanat UUPA yaitu dilakukannya pendaftaran tanah terlebih dahulu.

\section{Perlindungan hukum terhadap kreditor jika terjadi wanprestasi dari pihak debitor yang memberikan jaminan tanah berupa Girik}

Hak tanggungan merupakan hak preference dari kreditor pemegang hak tanggungan terhadap jaminan atas tanah yang diserahkan debitor sebagai jaminan pelunasan atas kredit yang diterimanya dari kreditor. Hak prefernce ini berlaku ketika debitor wanprestasi. Hak preference ini merupakan hak yang diperoleh kreditor setelah hak-hak piutang negara, misalnya adanya hutang pajak yang belum dibayar. Hutang pajak ini harus dilunasi terlebih dahulu, kemudian kreditor pemegang hak tanggungan akan mendapatkan hak preferencenya.

Obyek dari hak tanggungan adalah tanah dan atau benda-benda yang berkaitan dengan tanah baik secara keseluruhan ataupun hanya benda-benda yang berdiri diatas tanah tersebut. 
Adanya pembebanan hak tanggungan ini bertujuan agar kreditor mempunyai hak prefence atau hak yang didahulukan untuk mendapatkan pelunasan dari pada kreditor lainnya. Maksudnya adalah bahwa pemegang hak tanggungan mempunyai hak untuk dilunasi terlebih dahulu dari pada kreditor lainnya yang mana pelunasan hutang debitor di peroleh dari hasil penjualan jaminan yang diserahkan oleh debitor baik secara langsung maupun melalui pelelangan.

Pasal 10 Ayat (3) UUHT menyebutkan pelaksanaan pemberian hak tanggungan dapat dilakukan bersamaan dengan pendaftaran tanah khususnya untuk hak atas tanah yang berasal dari konversi hak lama. Pendaftaran tanah ini tentu mengacu kepada PP Nomor 24 Tahun 1997 Tentang Pendaftaran Tanah.

Berdasarkan hukum tanah nasional yang menganut asas pemisahan horizontal, maka antara benda-benda yang berdiri diatas tanah bukan serta merta menjadi satu kesatuan dengan tanahnya kecuali secara tegas oleh pemberi hak tanggungan di akta pembebanan hak tanggungan (APHT). Benda-benda yang berdiri diatas tanah ini meliputi bangunan, tanaman dan hasil karya. Kegiatan pembebanan hak tanggungan harus melalui dua tahap, yaitu :

a. Tahap pemberian dan pembuatan hak tanggungan.

b. Tahap pendaftaran APHT di kantor pertanahan.

Antara Pejabat Pembuat Akta Tanah selaku pejabat yang berwenang untuk mengeluarkan hal-hal yang berhubungan dengan pertanahan dalam hal ini yaitu APHT dan atau SKMHT, memberikan penyelesaian pada kreditor dan debitor yang menyerahkan jaminan hak milik belum terdaftar yaitu dengan menandatangani SKMHT dengan tetap melakukan proses pendaftaran hak milik yang belum bersertipikat tersebut. Apabila hak milik yang belum bersertipikat tersebut sedang proses pendaftaran maka dalam jangka waktu tertentu kemudian dibebani hak tanggungan dengan cara menandatangani APHT.

Tanah dengan alas hak yang belum didaftarkan yang masih berupa Girik (Letter C) menurut PBI No 13/26/PBI/2011 digolongkan sebagai salah satu jaminan dengan nilai pengurang pembentukan PPAP yang termasuk cukup kecil nilainya dibandingkan dengan tanah dengan alas hak milik berupa sertipikat. Hal ini merupakan salah satu upaya perlindungan hukum serta menjadi acuan dan pedoman bagi BPR selaku kreditor dalam mengambil langkah-langkah antisipatif untuk mencegah kerugian yang lebih besar.

Selama ini bank memang tetap menerima jaminan belum bersertipikat tersebut, walaupun dalam kenyataannya bank mempunyai risiko tidak dapat melakukan eksekusi terhadap jaminan dikarenakan tidak dibebani hak tanggungan. risiko yang mungkin terjadi 
pada bank dapat diminimalisir dengan melakukan monitoring pada debitor sebelum wanprestasi yang mengakibatkan timbulnya kredit macet. Hal-hal lain yang dilakukan bank untuk mencegah timbulnya kredit macet adalah dengan melakukan penyelamatan kredit, yang terdiri dari :

a. Rescheduling (Penjadwalan kembali).

b. Reconditioning (Persyaratan kembali).

c. Restructuring (Penataan kembali).

Bank dalam meminimalisir kerugian akibat debitor yang wanprestasi seringkali menggunakan asuransi. Kredit yang dijamin dengan asuransi harus tertulis dalam perjanjian kredit, dan atas kredit tersebut tersebut harus dengan banker's clause yang jangka waktunya minimal harus sama dengan jangka waktu kredit. Banker's clause merupakan klausula yang mengakibatkan hak bagi bank untuk menerima sejumlah uang pertanggungan dari klaim yang dicairkan oleh pihak asuransi apabila debitor wanprestasi. Klausul banker's clause harus jelas tertulis dalam perjanjian kredit dan tercantum dalam polis asuransi.

Bank dalam menghadapi debitor yang wanprestasi tidak serta merta langsung melakukan write off dan atau eksekusi jaminan, dikarenakan bank harus melakukan beberapa prosedur terhadap debitor wanprestasi yang biasa disebut dengan restrukturisasi kredit. Restrukturisasi kredit dapat dilakukan terhadap debitor dengan kriteria :

a. Debitur mengalami kesulitan pembayaran pokok dan/atau bunga Kredit; dan

b. Debitur memiliki prospek usaha yang baik dan diperkirakan mampu memenuhi kewajiban setelah Kredit direstrukturisasi.

Restrukturisasi kredit ini bertujuan untuk mengubah dari kategori diragukan atau macet menjadi paling tinggi kurang lancar atau paling tidak sama dengan kualitas sebelum dilakukan restrukturisasi kredit. Upaya bank dalam restrukturisasi kredit adalah dengan memberikan kebijakan tertentu pada debitor wanprestasi, yaitu :

a. Menurunkan suku bunga kredit.

b. Memperpanjang jangka waktu kredit.

c. Mengurangi tunggakan bunga kredit.

d. Mengurangi tunggakan pokok kredit.

e. Menambah fasilitas kredit, dan atau

f. Melakukan konversi kredit menjadi penyertaan modal sementara

Debitor yang bermasalah atau yang mengalami penundaan pembayaran kewajibannya terutama dalam hal ini yang menggunakan hak milik yang belum bersertipikat atau masih 
dalam bentuk Girik (Letter C) sebagai jaminan kredit memang harus mendapatkan perhatian yang khusus, mengingat jaminan yang belum bersertipikat tersebut tidak dapat dilakukan eksekusi hak tanggungan, oleh sebab itu bank harus melakukan pembinaan dan pengawasan yang intensif pada debitor.

\section{Simpulan}

Girik (Letter C) bukan merupakan bukti kepemilikan hak atas tanah berdasarkan peraturan yang berlaku, namun hanya sebagai bukti pembayaran pajak. Girik (Letter C) harus dikonversi untuk memperoleh legalitas kepemilikan. Meskipun demikian, Girik masih diakui keberadaanya yaitu sebagai bukti pendaftaran hak atas tanah untuk pertama kali. Dengan demikian maka pemerintah melalui peraturan perundang-undangan memberi formulasi bagi masyarakat pengguna jasa kredit bank agar dapat menjaminkan tanahnya tersebut dengan catatan harus didaftarkan secara bersamaan pada kantor pertanahan sesuai Pasal 10 Ayat (3) UUHT.

Bank dalam menerima jaminan berupa Girik (Letter C) dapat memenuhi legalitas jaminannya melalui proses dengan bantuan Notaris/PPAT yaitu dengan menandatangani Surat Kuasa Membebankan Hak Tanggungan (SKMHT) bersamaan dengan melakukan proses pendaftaran tanah atas Girik tersebut. Kemudian dalam jangka waktu tertentu dapat dibebani hak tanggungan dengan cara menandatangani Akta Pemberian Hak Tanggungan (APHT).

Diharapkan masyarakat dapat memahami betapa pentingnya pendaftaran tanah untuk memperoleh kepastian status legalitas tanah mereka, agar tanah yang sudah mendapatkan legalitasnya tersebut dapat dipergunakan salah satunya sebagai jaminan dalam perkreditan modal usaha mereka. Diperlukan semangat dari pemerintah untuk selalu mensosialisasikan gerakan pendaftaran tanah secara nasional. Hal ini tentu akan sangat membantu masyarakat terutama yang akan mempergunakan tanah mereka untuk dijadikan jaminan memperoleh modal usaha.

\section{DAFTAR PUSTAKA}

\section{A. Buku}

Badriyah, Siti Malikhatun. 2010. Penemuan Hukum Dalam Konteks Pencarian Keadilan. Semarang : Badan Penerbit Universitas Diponegoro Semarang

Jakarta : Sinar Grafika

2016. Sistem Penemuan Hukum Dalam Masyarakat Prismatik,

Busro, Achmad. 2017. Hukum Perikatan Berdasar Buku III KUHPerdata. Yogyakarta : Penerbit Pohon Cahaya

Gozali, Djoni S. dan Usman, Rachmadi. 2012. Hukum Perbankan. Jakarta : Sinar Grafika 
Harsono, Boedi. 1962. Hukum Agraria Indonesia. Jakarta : Penerbit Djambatan

Masjehoen, Sri Soedewi. 1975. Hak Jaminan Atas Tanah, Yogyakarta : Liberty

Moleong, Lexy J. 2009. Metodologi Penelitian Kualitatif. Bandung : PT Remaja Rosdakarya

Nasution, Dari S.1986. Metode Penelitian Naturalistik. Bandung : Tarsito

Parangin, Effendi. 1989. Hukum Agraria di Indonesia, Suatu Telaah dari Sudut Pandang Praktisi Hukum. Jakarta : Rajawali

1989. Praktek Penggunaan Tanah Sebagai Jaminan Kredit. Jakarta : Raja Grafindo Persada

Poerwandari, Kristi. 2005. Pendekatan Kualitatif dalam Penelitian Perilaku Manusia. Depok: LPSP3 FP UI

Santoso, Urip. 2005. Hukum Agraria dan Hak-Hak atas Tanah. Jakarta:Prenada Media

Siamat, Dahlan, 2005. Manajemen Lembaga Keuangan Kebijakan Moneter dan Perbankan. Jakarta : Lembaga Penerbit Fakultas Ekonomi Universitas Indonesia

Soemitro, Ronny Hanitijo. 1982. Metode Penelitian Hukum. Jakarta : Ghalia

Subekti dan Tamara, J. 1961. Kumpulan Putusan Mahkamah Agung mengenai Hukum Adat. Jakarta: Gunung Agung

Suharnoko. 2014. Hukum Perjanjian, Teori dan Analisa Kasus. Jakarta: Kencana Prenadamedia Goup

\section{B. Jurnal Ilmiah}

Badriyah, Siti Malikhatun. Problematika Pembebanan Hak Tanggungan Dengan Objek Tanah Yang Belum Bersertipikat. Jurnal Masalah-Masalah Hukum, Vol. 45, No. 2. 2016. Semarang : Fakultas Hukum Universitas Diponegoro.

\section{Peraturan Perundang-Undangan}

Undang-Undang Dasar Negara Republik Indonesia Tahun 1945

Kitab Undang-Undang Hukum Perdata

Undang-Undang Republik Indonesia Nomor 7 Tahun 1992 Tentang Perbankan Sebagaimana Telah Diubah Dengan Undang-Undang Nomor 10 Tahun 1998

Undang-Undang Nomor 5 Tahun 1960 tentang Peraturan Dasar Pokok-Pokok Agraria.

Undang-Undang Nomor 4 Tahun 1996 Tentang Hak Tanggungan Atas Tanah Beserta BendaBenda Yang Berkaitan Dengan Tanah

Peraturan Pemerintah Nomor 10 Tahun 1961 Tentang Pendaftaran Tanah

Peraturan Pemerintah Republik Indonesia Nomor 24 Tahun 1997 Tentang Pendaftaran Tanah

Peraturan Menteri Negara Agraria/Kepala Badan Pertanahan Nasional Nomor 3 Tahun 1997 Tentang Ketentuan Pelaksanaan Peraturan Pemerintah Nomor 24 Tahun 1997 Tentang 
Pendaftaran Tanah

Peraturan Bank Indonesia Nomor :13/26/PBI/2011 Tentang Tentang Kualitas Aktiva Produktif Dan Pembentukan Penyisihan Penghapusan Aktiva Produktif Bank Perkreditan Rakyat

Surat Edaran Gubernur Bank Indonesia Nomor 14/ 26 /DKBU tentang Pedoman Kebijakan dan Prosedur Perkreditan bagi Bank Perkreditan Rakyat

\section{Website}

Haryanto. "Metode Pengumpulan Data", diakses dari http://belajarpsikologi.com/metodepengumpulan-data/ pada tanggal 25 Januari 2017. 